\title{
A contribution of the Cleaner Production Program to the ISO 14001 Management System: a case study in the metal-mechanic sector
}

\author{
Fernando Magnani Cervelini \\ NMHG-Brasil \\ aefcerve@nmhg.com \\ cervelini@vivax.com.br \\ Maria Tereza Saraiva Souza \\ Uninove \\ mtereza@uninove.br
}

\begin{abstract}
The aim of this work is to identify the contributions of the Cleaner Production Program to the Environmental Management System certified to ISO 14000. The results of the research indicate that the procedure standardization demanded by normalization leads the company to adopt environmentally adequate procedures; besides, the implementation of the Cleaner Production Program acts as a complementary tool in the EMS, with a view to improving environmental performance.
\end{abstract}

KEY WORDS: ISO 14000; Environmental Management System; Cleaner Production

\section{INTRODUCTION}

Nowadays, environmental tools can reorient the production process of goods and services. An Environmental Management System certified to ISO 14001 is regarded as one of the most adequate instruments to improve business performance and expansion. Some studies, however, show that the creation of the Environmental Management System certified to ISO 14001 does not guarantee a change towards greater environmental responsibility in the production system.

For industries in developing countries to promote sustainable development and face competition in the global market, much more is needed than the obtainment of ISO 14000 certification. It is important that products, services and production patterns be revised with a view to cleaner and more efficient production, with lower cost and better quality products.

The presupposition that oriented this research was that an Environmental Management System based on ISO 14000 norms complies with the legislation; however, there are opportunities for improvement in the system, with the insertion of Cleaner Production Program concepts.

With this scenario in mind, the aim of this work was to identify the contributions of the Cleaner Production Program to an Environmental Management System - EMS - certified to ISO 14001, aiming at the improvement of environmental conduct in goods and service provider organizations. The unit of analysis for the study was the Environmental Management System - EMS - certified to ISO 14001 of a metalmechanic sector company.

\section{RESEARCH METHODOLOGY}

This research adopted the methodology of single case study. The company chosen is a leading multinational company in the metal mechanic sector, manufacturing equipment for moving goods, with the Environmental Management System certified to ISO 14001 in 2002 and re-certification in 2006.

Taking into consideration the factors mentioned by Yin (2001), as regards the company chosen and the sector, the justification for single case study is 
the fact that it represents a decisive case, because it fulfils the conditions required to test the aims proposed. It creates the appropriate conditions for the comprehension, the contestation or the confirmation of the theory, and it is conducted as an introduction to a detailed study, with the utilization of exploratory mechanisms. According to Siggelkow (2007), the cases studies can be used in the context of making a conceptual contribution to employ them as illustration.

Various sources of evidence were used in this work, allowing for the development of convergent lines of investigation by means of a triangulation process of information from different data sources (Yin, 2001). The data collection instruments used were documents, archive records, interviews, direct and participant observation.

The following documents from the company were analyzed: Environmental Management System Manual; documented communication between the company and environmental authorities; investment charts for environmental matters; Effluent Treatment Plant and industrial process operation flow charts; graphics and tables with environmental indicators; minutes of meetings pertaining to the Environmental Management System; environmental aspects and impact charts; waste management procedures; documents related to the company's environmental liabilities; questionnaires on environmental practices for suppliers; Effluent Treatment Plant control reports; service orders; raw material entries; water use cycle; production process documents; environmental management plan; environmental control plan.

The records used were: Corrective Action and Preventive Action (CAPA); internal procedure and work instructions; annotations of non-conformity environmental occurrences found by internal and external auditing; waste destination control charts; annotations of water and electricity consumption.

With the bibliographical research as a base, it was possible to elaborate a schedule for the interviews. The interviews consisted of questions related to the environmental system, and the aim was to analyze performance and to identify opportunities for improvement in the company's Environmental Management System certified to ISO 14001. The interviewees were the people directly responsible for the administration of the Environmental Management System: supervisors who took part in the implemen- tation of the Environmental Management System, staff in general and external environmental consultants who help in the maintenance of the Environmental Management System - 19 people in all. The questions were sent previously so that interviewees could prepare the answers and seek for information they did not have at hand.

Two different kinds of direct observation, formal and informal, were used in this case study. Formal observation implied participation in meetings pertaining to the EMS. Informally, waste storage areas, handling of products and waste, pollution sources and effluent reuse were observed. Participant observation was also an instrument in this study, as the author takes part in activities related to EMS in the company.

Triangulation was carried out making use of the results obtained in the interviews, the analysis of documents and records in the Environmental Management System archives, plus direct observation and participant observation.

\section{THEORETICAL BACKGROUND}

The first manual on how to minimize industrial waste in manufacturing processes was published by the Environmental Protection Agency - US (EPA) in 1988. The second manual was published in 1991 by two UNO agencies: United Nations Environmental Program (UNEP) and United Nations Industrial Development (UNIDO). The text Audit and Reduction Manual for Industrial Emissions and Wastes was drafted in the context of the Cleaner Production Program, to be used by professionals in the industrial sector, consultants and government authorities interested in improving relations between industry and the environment.

According to Centro Nacional de Tecnologias Limpas, CNTL/SENAI (the National Center for Clean Technologies) the main objective of Cleaner Production is to eliminate or reduce the emission of pollutants in the environment, while optimizing the use of raw materials, water and energy.

To Barbieri (2004), Cleaner Production is characterized by actions that aim at reducing waste and emissions at the source, therefore priority should be given to measures that try to eliminate or minimize waste, effluents and emissions in the production process wherever they are generated.

Cleaner Production actions are given priority according to the flow chart in figure 1. 
Figure 1. Cleaner production flow chart

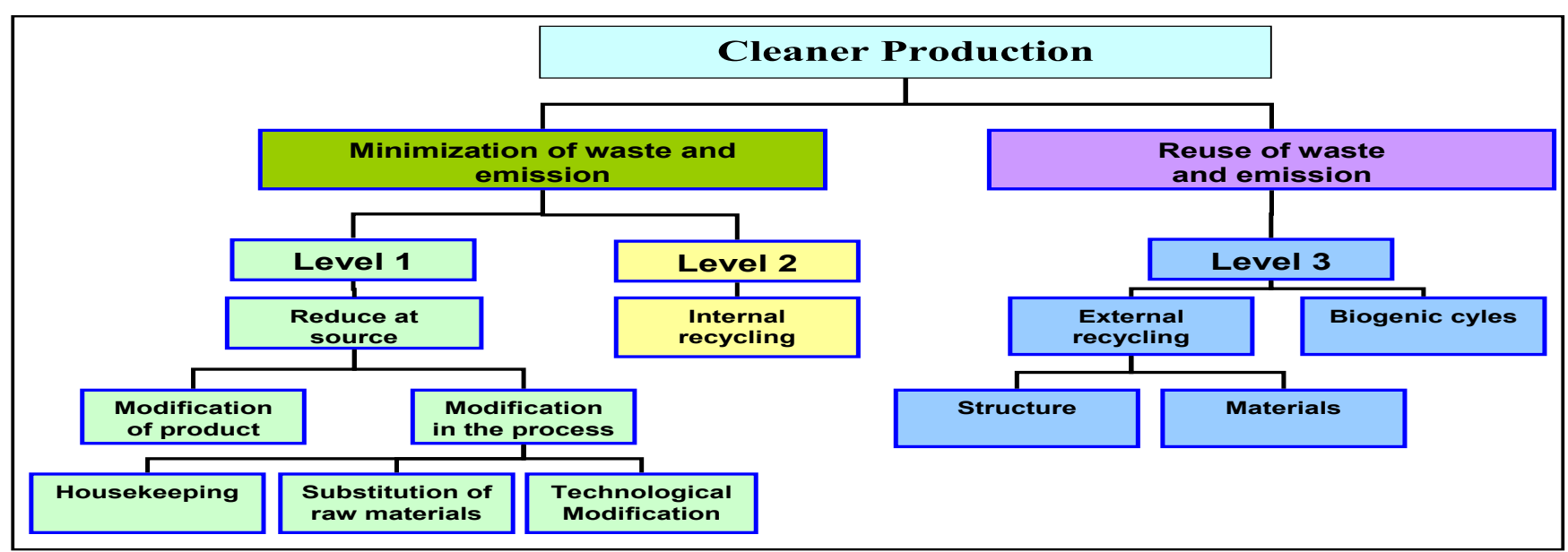

Source: Centro Nacional de Tecnologias Limpas - CNTL/SENAI (2004)

It should be observed that at Level 1: Reduction at source, priority is given to actions that aim at reducing the generation of waste and emissions at the generating source. When it is not possible to adopt the measures suggested at Level 1, moving on to Level 2, the aim is to optimize the internal cycle of the company with the reuse of waste generated, within the process itself or in another process in the company. Level 3 comes into being when waste and emissions generated cannot be reused in the same production unit where they were generated.

Thus, options available for Cleaner Production must be analyzed and selected with priority being given, whenever possible, to Level 1 alternatives (reduction at source), followed by Level 2 actions (internal recycling), with Level 3 (external recycling and biogenic cycles) as a last resort.

According to CORBETT (2001), The effect of iso 14001 as an emissions reducer weakened, while the effect power of the environmental management system to reduce emissions became stronger.
To Klassen (1993), by including both environmental and quality factors in the new products and process, the continuous improvement over the long term is possible.

\subsection{Comparing ISO 14001 and Cleaner Production}

Cleaner Production, when compared to ISO 14001, presents the following advantages: a potential for economical solutions, with a reduction in the amount of materials and energy used; scope for innovation in the company, as a result of the evaluation of the production process; minimization of waste, effluents and emissions; reduction of risks in the areas of environmental obligations and disposal of waste, since responsibility is assumed for the production process as a whole; definition of directives for sustainable economic development.

According to LaGrega et al. (1994), the conditioning factors "technologies" and "procedures" must evolve towards the composition of scenarios that are more environmentally adequate, as seen in Figure 2. 
Figure 2: Technologies e environmental procedures

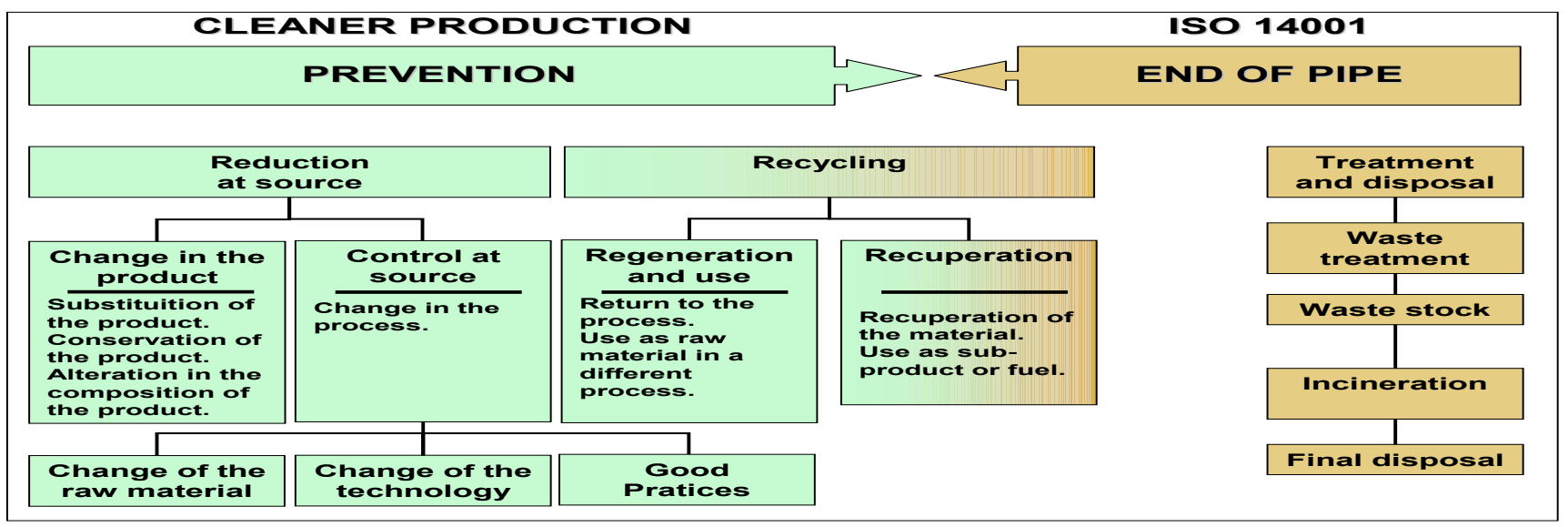

Source: LaGrega et al, (1994)

Figure 2 presents the evolution of technologies and procedures reflecting the differences in an Environmental Management System that employs preventive strategies, represented by Cleaner Production, or an EMS using End of Pipe strategies, represented by the system based on ISO 14000 norms.

LaGrega's organization chart (figure 2) may be useful in the definition of Cleaner Production techniques to be adopted in the production process, since it presents examples of measures to be taken and indications of priority order (from left to right). Therefore, the most desirable option is the adoption of "reduction at source" techniques, followed by internal recycling, then external recycling and finally End of Pipe technologies, found in the last column on the right (waste treatment and disposal).

Furtado (1998) affirms that both ISO 14001 and Cleaner Production contribute towards improving environmental conduct in organizations that provide services and produce goods, but are different in their objectives, methodologies and targets. To Cobertt (2001), the ISO 14001 systems is not bring the immediate benefits if the company goal is reduce the emission, but it must be analysed if the customer requires an iso 14001 system

In Table 1, é doa study comparing an Environmental Management System based on ISO 14001 é norms and Cleaner Production is presented. 
Table 1: A comparison between EMSs: ISO 14001 x Cleaner Production

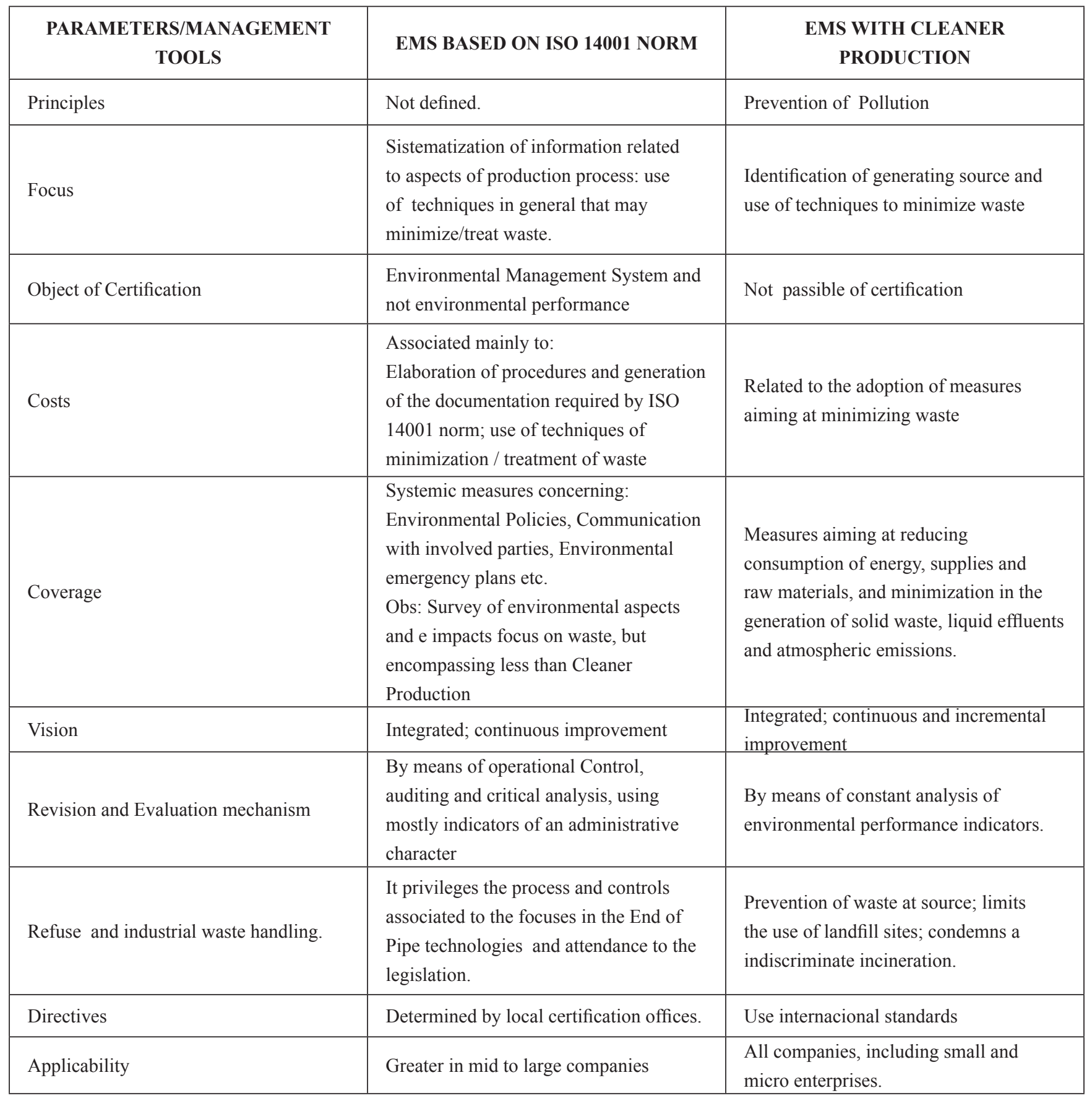

Source: based on Kiperstok, et al. (2002)

As observed in Table 1, the focus of an EMS based on ISO 14001 norms is on information systematization, with the aim of identifying mechanisms used to manage environmental aspects and impacts, without a preoccupation with the underlying directive principle.

Table 2 may provide further orientation for the insertion of Cleaner Production concepts into an Environmental Management System based on ISO 14001 norms. 
Table 2: A proposal for insertion of the Cleaner Production model into ISO 14001 requisites (2004).

\begin{tabular}{|c|c|}
\hline ISO 14001 REQUISITES & EMPHASIS/ MAIN APPROACH \\
\hline 4.2- Environmental Policies & $\begin{array}{l}\text { Commitment to Cleaner Production in the shape of prevention of } \\
\text { Pollution. }\end{array}$ \\
\hline 4.3.1- Environmental Aspects & $\begin{array}{l}\text { Survey of aspects and evaluation of impacts using Cleaner } \\
\text { Production opportunities as a significance filter. }\end{array}$ \\
\hline $\begin{array}{l}\text { 4.3.1- Objectives and Goals } \\
\text { 4.3.2- Environmental Management Programs }\end{array}$ & $\begin{array}{l}\text { Objectives and goals made viable through projects with a focus on } \\
\text { Cleaner Production. }\end{array}$ \\
\hline 4.4.1-Structure and responsibility & Resources for the implementation of such projects \\
\hline 4.4.2-Training, raising awareness and competence. & $\begin{array}{l}\text { Raising awareness; training for the implementation of Cleaner } \\
\text { Production projects (methodology, concepts and technology). }\end{array}$ \\
\hline 4.4.6- Operational Control & $\begin{array}{l}\text { Activities identified as Cleaner Production opportunities must } \\
\text { be planned and programmed in order to provide support for all } \\
\text { activities in the projects implemented. }\end{array}$ \\
\hline 4.5.1-Monitoring and measurement & $\begin{array}{l}\text { Creation of indicators to monitor results and parameters related } \\
\text { to the projects, and as a consequence, of objectives and goals to } \\
\text { be reached. }\end{array}$ \\
\hline 4.5.4-EMS internal auditing & $\begin{array}{l}\text { Independent verification of the rhythm of Cleaner Production } \\
\text { provisions. }\end{array}$ \\
\hline 4.6- Critical analysis by the administration & $\begin{array}{l}\text { Semiannual/annual balance sheets with inclusion of results and } \\
\text { proposals for improvements, with Cleaner Production projects as } \\
\text { an important input. }\end{array}$ \\
\hline
\end{tabular}

Source: based on Prestrelo and Azevedo (2000).

Table 2 emphasizes the requirements of the environmental system based on ISO 14001:2004, which may be considered points of insertion for concepts of the Cleaner Production model.

\section{ANALYSIS AND DISCUSSION OF RESULTS}

In terms of environmental impacts, waste is the greatest problem and the essence of Cleaner Production is the optimization in the use of natural resources and the reduction or elimination of waste. Thus, the aim of this item is to analyze the Waste Management System and the way natural resources are used in the company studied.

According to the interviews carried out, generation and destination of waste are not the main preoccupation regarding the maintenance of the Environmental Management System in the company. It was possible to verify that $85 \%$ of the interviewees believe that the Environmental Management System based on ISO 14001 is not sufficient for a good performance in environmental conduct. Only 10\% of the interviewees demonstrated that they knew about and could identify concepts of the Cleaner Production Program developed by UNEP (1998). The main concepts identified are related to actions aiming to prevent and minimize waste at source.

Figure 3 presents the items and the importance attributed to them by interviewees, representing the main concerns regarding the EMS implemented. 
Figure 3: Concerns regarding the EMS

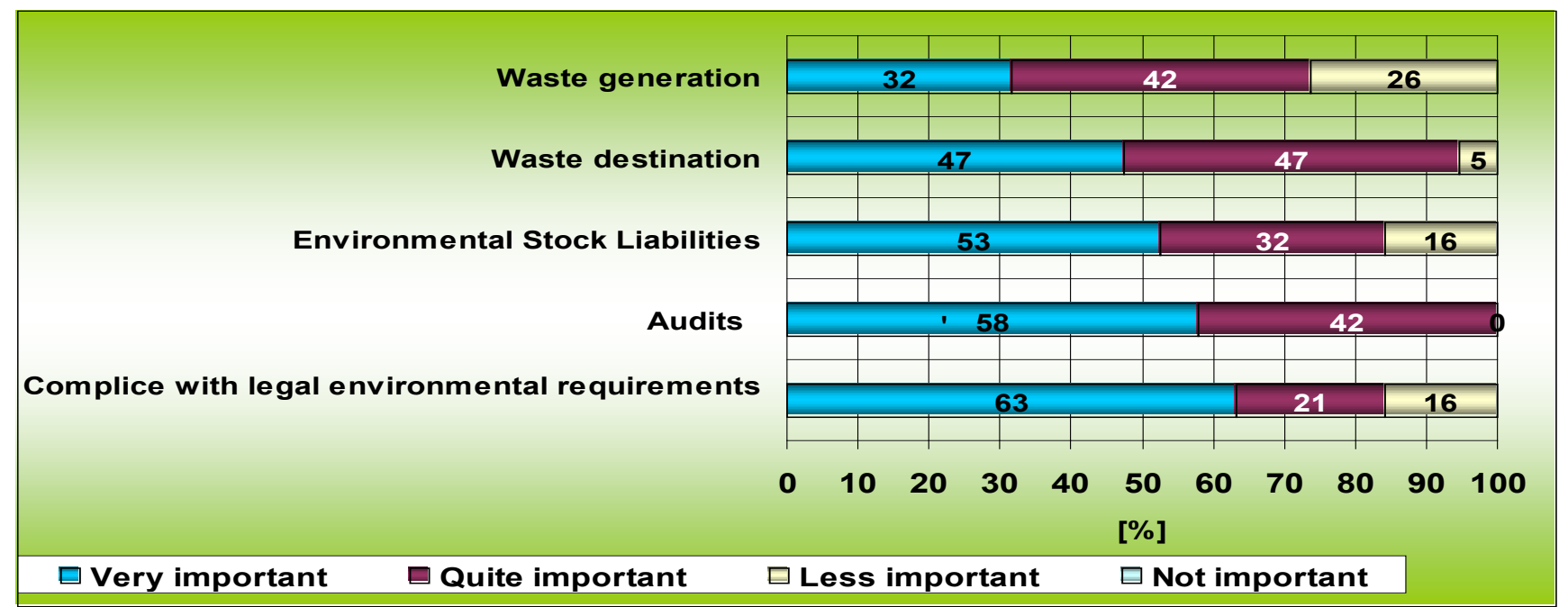

Source: based on the results of the interviews

According to Figure 3, 63\% of the interviewees defined "Compliance with legal environmental requirements" as "very important" for the EMS implemented. The item "Auditing" was considered "very important" by $58 \%$ of the interviewees. "Environmental liabilities", " Waste Destination" and

"Waste Generation" were regarded as "very important" by 53\%, 47\% and 32\% of the interviewees respectively.

The data below refer to the analysis of documents and records in archives pertaining to the EMS of the company and to Direct and Participant Observation.

\subsection{WASTE GENERATING PROCESSES AND DESTINATION}

Production process analyses were carried out by means of direct observation, examination of the EMS documents and interviews that resulted in the production of Table 3, which details the stages in the production process with the waste generated in each stage and its destination.

Table 3: Stages in the production process, waste and destination.

\begin{tabular}{|l|l|l|}
\hline \multicolumn{1}{|c|}{ Item } & \multicolumn{1}{|c|}{ WASTE GENERATED } & DESTINATION \\
\hline 1 & $\begin{array}{l}\text { Sanitary waste; rubble; asbestos roof tiles; litter from sweeping and cleaning; Effluent } \\
\text { Treatment Plant sludge }\end{array}$ & Landfill site \\
\hline 3 & Waste from clinic; material contaminated with paint, oil and solvent & Incineration \\
\hline 4 & Wood & Burned in furnace \\
\hline 5 & $\begin{array}{l}\text { Paint dregs; oxycutting dregs; cooking oil; used batteries; industrial cloth contaminated } \\
\text { remover; solvent; oil emulsion; tires and rubber }\end{array}$ & External recycling \\
\hline 6 & Oxycutting scraps; metal scraps; paper, plastic and cardboard; metal splinters & External recycling (sale) \\
\hline 7 & Water contaminated with paint, solvent and oil & Internal Recuperation \\
\hline 8 & Cesspool sludge & External treatment \\
\hline 9 & Coal and quartz; hydrocarbon; coal contaminated with hydrocarbon & Not defined \\
\hline
\end{tabular}

Source: based on the company's EMS documents (2006) 
The classification of the destination of each type of waste, presented in Table 3, was based on the criteria defined by LaGrega (1994), UNEP (1998) and (CNTL/SENAISENAI) (2003).

With the analysis of documents, Instructions, Internal Communications, Effluent Treatment Plant Operation Control charts and Service Orders available, it was possible to verify that the company generates 34 types of waste; 27 are monitored through Waste Destination Charts and 5 of those types are considered Environmental Indicators and are presented in the organization's Environmental Management Plan. They are: wood, material for incineration, landfill, paint dregs, paper/plastic and cardboard.

The analysis of the costs of the most significant waste generated led to the elaboration of Figure 4, which presents the most important items of waste, classified according to importance in terms of costs.

\section{Figure 4: Most significant waste and destination costs}

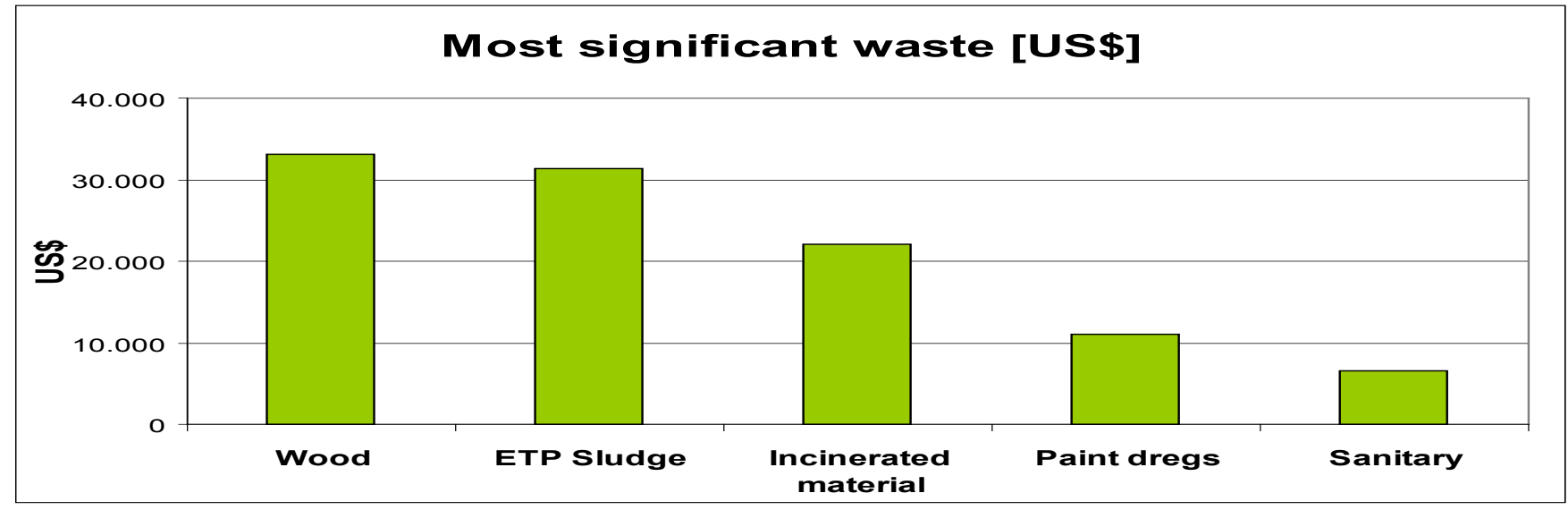

Source: Based on the company's EMS documents (2006)

In Figure 4, it may be observed that wood is responsible for the highest annual cost incurred by the company with waste destination, even though the destination for burning in the furnaces accounts for only $3 \%$ of the total, considering all types of destination.

The annual cost incurred for the destination of the Effluent Treatment Plant sludge is the second highest. It should be noted that the water treatment process accounts for $18 \%$ of all types of waste generated in the company and is responsible for the generation of approximately $15,000 \mathrm{~kg}$ of sludge per annum.

Destination of waste for incineration costs about US\$22,000 per year, although only $6 \%$ of all types of waste are disposed of through incineration.

The costs incurred for the destination of paint dregs originating from the trimestral cleaning of paint booths plus sanitary waste come up to approximately US\$17, 000 per year. Paint dregs are the most significant waste sent out for external recycling - approximately $34,000 \mathrm{~kg} / p . a$. at a yearly cost of US\$11,000.

\subsection{STRATEGIES FOR REDUCTION, WASTE CONTROL AND USE OF NATURAL RESOURCES}

Strategies for each type of waste generated may be identified and analyzed, with figure 5 as a basis. It presents the techniques for waste control that are being adopted by the company at present, based on the Environmental Management System implemented. 
Figure 5: Techniques for waste control

Techniques for waste control

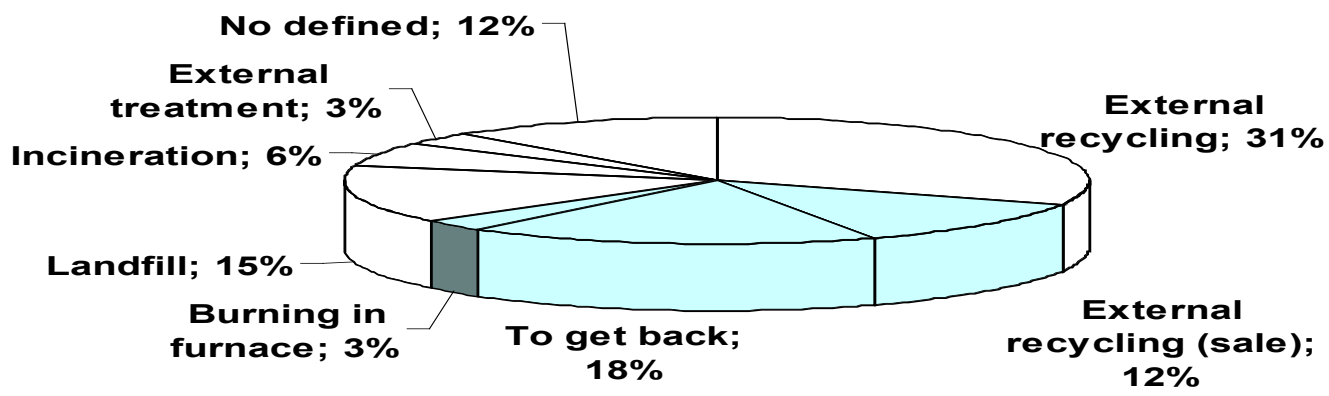

Source: based on the company's EMS documents (2006)

It should be stressed that, according to the interviewees, waste generation is not the main concern as regards the Environmental Management System implemented. Compliance with legal requirements and external Environmental Auditing are mentioned by the interviewees as the main concern regarding the Environmental Management System maintenance.

The aim of this item is to analyze the practices adopted for waste reduction, considering the EMS implemented, and which concepts from the Cleaner Production Program may be used with a view to improving the environmental conduct of the company. This analysis was based on the results obtained in the case study and in the revision of the literature, including the Environmental Protection Technology Evolution chart suggested by
LaGrega (1994); and the Cleaner Production Flux proposed by UNEP (1998) e CNTL/SENAI (2003).

The evaluation of the company's environmental conduct, based only on the Cleaner Production Flow chart (Figure 1), adopted by UNEP and CNTL/SENAI, may not indicate important aspects that are verified when LaGrega's diagram of technology evolution and environmental procedures is used. This diagram considers the End of Pipe technologies as the starting point for the evolution of strategies adopted to reduce pollution.

Table 4 lists the criteria for priority level classification of waste reducing alternatives, as proposed by UNEP e CNTL/SENAI (2003), and the evolution of waste reduction strategies suggested by LaGrega.

Table 4: Evolution of pollution reduction strategies based on Cleaner Production

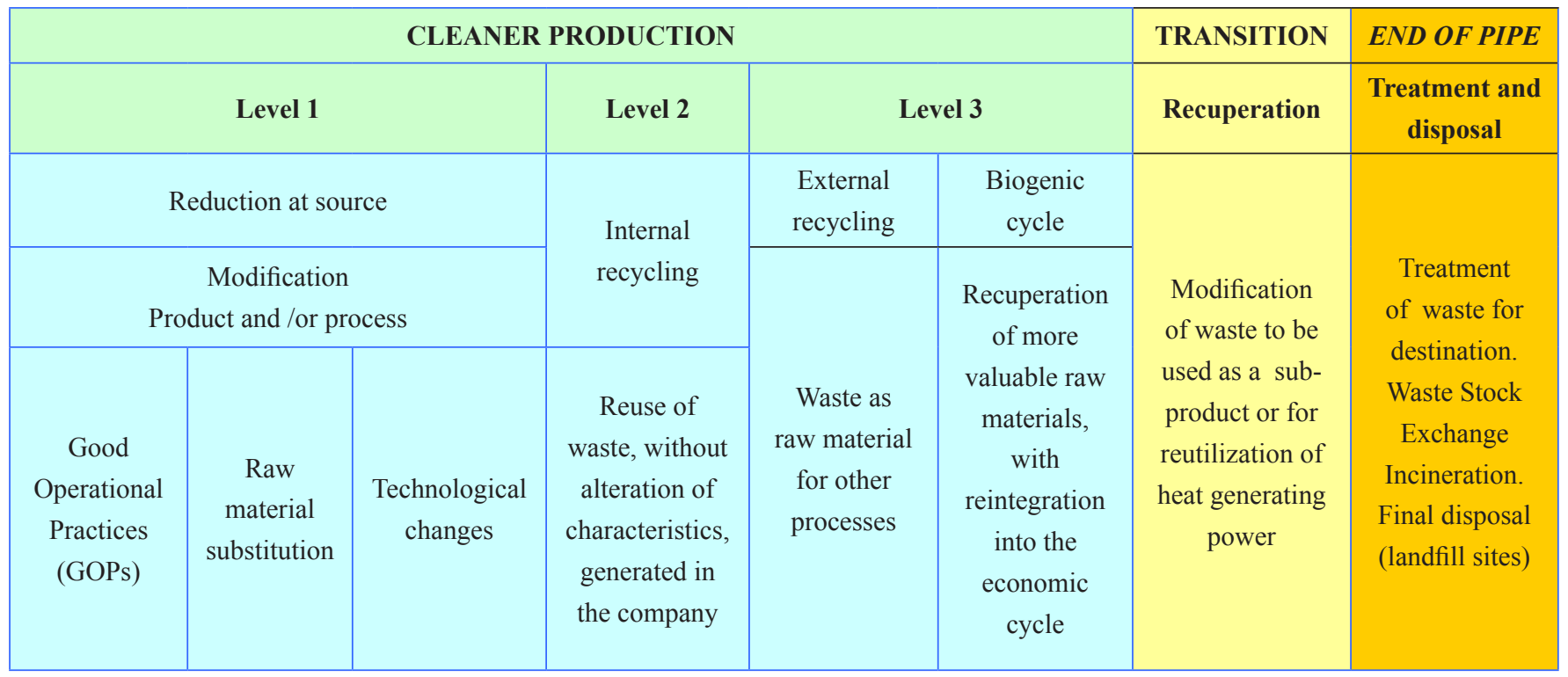

Source: based on LaGrega (1994). 
Table 4 proposes that the analysis of strategies adopted for pollution reduction should be done considering End of Pipe technologies, the phase of transition in environmental conduct between End of Pipe and Cleaner Production and priority levels in the Cleaner Production program.

\subsubsection{End of Pipe Technology}

According to De acordoKiperstok et al (2000), waste disposal in landfill sites of any kind characterizes the adoption of End of Pipe strategies. As observed in Table 3 and Figure 5, waste destined to landfill sites represents $15 \%$ of all waste generated, although $100 \%$ of that waste originates in secondary activities in the company studied. Kitchen and toilet waste, as well as waste from refurbishing and remodeling, are destined to Class II landfill sites; sludge resulting from effluent treatment is destined to Class I landfill sites.

According to LaGrega et al (1994) and to Table 4, waste incineration is also considered an End of Pipe strategy, and corresponds to thermal oxidation under high temperatures. This process is adopted to reduce volume and weight.

Waste destined to incineration represents $6 \%$ of the waste generated in the company, with $99.5 \%$ of it generated in the painting process and approximately $0.5 \%$ resulting from activities in the company's clinic.

In this specific case, "waste destined for external treatment" is the sludge from the cesspools and kitchen sewage inspection boxes, which is destined to SABESP (the local water and sewage company) for appropriate treatment and represents $3 \%$ of all waste generated by the company. As shown in Figure 5 and table $3,12 \%$ of the waste is awaiting definition for external treatment or final disposal, according to legislation. At present, this type of waste is stored in metal containers in the area set aside for waste.

Although the different types of waste mentioned in the previous paragraph are classified as "not defined" in Figure 5, they pertain to End of Pipe technology, according to Table 4, since that waste is destined to classified landfill sites or directed for external treatment, as it has characteristics that prevent its use in the internal recycling process at present. Considering the course of action adopted for waste destination, it can be noticed that End of Pipe technology is employed for $36 \%$ of the waste generated in the company.

\subsubsection{Transition between End of Pipe technology and Cleaner Production}

According to Kiperstok et al (2000) and LaGrega et al (1994), the caloric power of waste used as fuel and the modification of liquid effluent to be used as a sub-product are classified in the area of transition between End of Pipe technologies and Cleaner Production.

The analysis of Table 243 and Figure 35 shows that Transition between End of Pipe and Cleaner Production is the technique adopted for waste wood and for water contaminated with oil, paint and oxycutting dregs.

To Christie, Rolfe and Legrand (1995), recuperation of the energy in waste, through burning, and effluent treatment for use as sub-product are advisable techniques, but only for waste that is impossible to avoid after improvements in the process.

Wood burning in furnaces (3\%) and internal recuperation of contaminated water (18\%) presented in Figure 5 are classified as Transition Techniques between End of Pipe technologies and Cleaner Production.

The analysis of waste control documents showed that there was a significant increase in the generation of wood as waste in the comparison between years 2005 and 2006 ( until July/06). It should be mentioned that the increase was due to modifications in the forklift truck manufactured, which demanded the substitution of suppliers, and they used wood crates as the main form of packaging parts. No action that could effectively lead to reduction of wood as waste was observed.

Water contaminated with oil, originating both from washing factory floors and equipment, and from contention and compressed air generation boxes is treated in the Effluent Treatment Plant, by means of a chemical process and later reused as a sub-product in the paint filtering system, for washing forklift trucks and for refrigeration in oxygraph cutting.

According to Fink (1995), the implementation of a water reuse system aims at reducing environmental impacts and promotes better environmental practices. Water reuse in the production process may be a viable alternative, which will, in conjunction with technical, economic and environmental evaluation of the production process and of the product, result in continuous improvement and a reduction of costs. 


\subsubsection{External Recycling and Reintegration to the biogenic cycle (Level 3)}

According to Table 254, waste control techniques classified at Level 3 correspond to external recycling techniques or biogenic cycle. In Figure 5, "external recycling 31\%" refers to waste that is disposed of through payment of the generating company; "external recycling (sale) $12 \%$ " refers to waste that is sold to companies that use it as raw material. Therefore, the overall sum of waste destined to external recycling is $43 \%$.

As seen in Table 3, waste destined for external recycling consists of, among other things, paint dregs; oxycutting dregs; cooking oil; used batteries; industrial cloth contaminated with oils and grease; light bulbs; antifriction lubricant; water with grease remover; oil emulsion and rubber.

"External recycling (sale)" refers to metallic waste generated in the production process or in maintenance actions and is presented in Table 5.

Table 5: Waste classified for external recycling

\begin{tabular}{|l|l|l|l|l|l|l|}
\hline \multirow{2}{*}{ WASTE } & \multicolumn{3}{c|}{ Qtty. (kg) } & \multicolumn{3}{c|}{ Sale Value (R\$) } \\
\cline { 2 - 7 } & \multicolumn{1}{|c|}{$\mathbf{2 0 0 4}$} & \multicolumn{1}{|c|}{$\mathbf{2 0 0 5}$} & $\mathbf{2 0 0 6}$ & $\mathbf{2 0 0 4}$ & \multicolumn{1}{|c|}{$\mathbf{2 0 0 5}$} & \multicolumn{2}{c|}{$\mathbf{2 0 0 6}$} \\
\hline Oxycutting scraps & 285,290 & 503,350 & 566,460 & 71,323 & 125,838 & 142,027 \\
\hline Metal scraps in general & 153,990 & 241,890 & 211,530 & 26,178 & 41,121 & 36,172 \\
\hline Metal splinters & 144,040 & 227,140 & 80,612 & 11,523 & 18,171 & 6,770 \\
\hline Paper, plastic and cardboard & 61,124 & 87,220 & 82,676 & 3,056 & 4,361 & 4,134 \\
\hline Total & 644,444 & $1,059,600$ & 940,278 & 112,080 & 189,491 & 189.103 \\
\hline
\end{tabular}

Source: based on the company's EMS documents (2006)

It should be noted that in the columns marked "Quantity" and "Sale value" for the year 2006, the value corresponds to eleven months of activities, i.e. January to November 2006. The analysis of Table 5 indicates that there was a reduction in the generation of splinters from the manufacture of metal cast pieces, even taking into consideration the fact that the index refers to eleven months of activities.

Each type of metallic waste destined to external recycling (sale) has different market values depending on their condition. According to the analysis of the charts the company received approximately US $\$ 100,000.00$ for the sale of metallic waste. It should be stressed that the Cleaner Production Program gives priority to actions that aim for reduction of waste at the generating source, with recycling techniques being classified as a Level 3 strategy.

According to Barbieri (2004), Level 3, though listed as one of the classification criteria for Cleaner Production alternatives, should not be given priority over Levels 1 and 2 in the Cleaner Production Program.

\subsubsection{Internal Recycling (Level 2)}

Internal Recycling is defined as reuse of waste generated in the company itself in the condition in which it is generated, i.e. without treatment or modification of physical and chemical characteristics. In this case study, actions classified as Level 2 alternatives for waste reduction were not noted, according to Table 4 .

\subsubsection{Reduction at source (Level 1)}

According to Friedmann (1997), at Level 1 priority should be given to actions that aim at reducing generation of waste at the generating source, with critical evaluation of materials used in the products. Through the analysis of EMS documents, besides observation and interviews carried out with those responsible for the management of the environmental system, it was possible to verify that only actions related to Good Operational Practices are found at Level 1 of the classification criteria (priority level alternatives to minimize waste).

The installation of transparent roof tiles in Stock Control areas and changing rooms, maximizing the use of natural light, and the more frequent maintenance of eighteen welding machines in order to improve the use of electricity are Examples of Good Operational Practices implemented in the company are examples of Good Operational Practices implemented in the company. 
As to changes in the product, it could be noticed that there was no alteration in the product aiming at minimizing environmental impacts. Similarly, no changes were observed in technology or the use of raw material.

\subsubsection{Use of Natural Resources}

Better use of natural resources is emphasized at Level 1 of the Cleaner Production Program. A reduction in the generation of waste and emissions at the source may occur through modifications in the production process by means of Good Operational Practices. These are the most adequate actions, since they optimize the use of natural resources.

In this case study, the natural resources studied were water and electricity, which are regarded by the company as environmental gauges and an integral part of the Environmental Management Program.

Table 6 is based on the Environmental Management Plan - EMP. It presents the per-capita consumption of drinking water.

Table 6: Water consumption

\begin{tabular}{c|c}
\hline Year & Consumption (m $\mathbf{m}^{3}$ person) \\
\hline 2004 & 3.11 \\
\hline 2005 & 2.83 \\
\hline 2006 & 2.33 \\
\hline
\end{tabular}

Source: based on the company's EMS documents (2006)

Though the index is calculated based on the number of people, it was observed that this resource is used in the industrial area as a complement to treated water, besides being used in the industrial kitchen, toilets, lavatories and showers. The water supply system only measures consumption of public supply water; therefore, it was not possible to obtain partial consumption records to verify how much drinking water is consumed in the production area.

As observed in Table 6: Water Consumption, there was a reduction of approximately $10 \%$ in mean water consumption between 2004 and 2005. Between 2005 and 2006 it decreased by $21.45 \%$. These percentages of reduction may be credited to actions of increased use of treated water in the production process, for example, to wash forklift trucks and as water curtain in the painting process. Awareness raising campaigns for reduction and rational use of drinking water were noted in the Environmental
Management Plan and during observation in the factory's premises.

It was noticed that the liquid effluent treatment process, classified as Transition Technology, is directly reflected in drinking water consumption in the company. According to drinking water consumption control records, the use of treated water in the production process instead of drinking water results in a reduction of approximately 54 cubic meters of water per month, since mean consumption of this resource is 530 cubic meters.

In Table 7: Electricity Consumption, electricity consumption per machine produced is presented.

\section{Table 7: Electricity consumption}

\begin{tabular}{c|c}
\hline Year & Consumption (MWh/machine produced) \\
\hline 2004 & $-\mathrm{X}-\mathrm{X}-$ \\
\hline 2005 & 0.79 \\
\hline 2006 & 1.12 \\
\hline
\end{tabular}

Source: based on the company's EMS documents (2006)

Rates for the year 2004 are not presented, because until that year the indicator was obtained considering the ratio of electricity consumption to hours of work. Research into electricity consumption charts and production indices (Kw/hour of work) verified that the indicator Kilowatt/hour per hours of work did not represent the real situation of energy use in the company. From 2005 onwards, a new indicator was adopted-Megawatt per machine produced $-(\mathrm{MWh} / \mathrm{mach}$.produced $)$ and, according to the Environmental Management Plan, the lower the index, the better the use in the production process.

After analyzing the strategies for reduction of waste and natural resources used, the next item presents the contributions of the Cleaner Production Program to an Environmental Management System certified to ISO 14001.

\subsection{CLEANER PRODUCTION CONTRIBUTIONS TO ISO 14001}

Actions related to the Cleaner Production strategies presented in the literature are directed towards the causes and the understanding of waste generation. In the End of Pipe technology approach, the first actions adopted are usually adequate disposal or waste treatment. 
Table 8 synthesizes actions adopted by the company to reduce pollution, listing the kind of technique used and the number of actions implemented.

Table 8: Pollution reduction techniques and number of actions implemented

\begin{tabular}{|l|l|l|}
\hline \multicolumn{2}{|c|}{ LEVELS AND TYPES OF TECHNIQUES TO REDUCE POLLUTION } & \multicolumn{1}{|c|}{$\begin{array}{c}\text { NUMBER OF ACTIONS } \\
\text { IMPLEMENTED }\end{array}$} \\
\hline \multirow{3}{*}{ LEVEL 1 (CP) } & Product or process modification & 0 \\
\cline { 2 - 3 } & Raw material substitution & 0 \\
\cline { 2 - 3 } & Modification of technology & 0 \\
\cline { 2 - 3 } & Good Operational Practices - GOPs & 2 \\
\hline \multirow{2}{*}{ LEVEL 2 (CP) } & Internal Recycling & 0 \\
\hline LEVEL 3 (CP) & External Recycling and biogenic cycles & 16 \\
\hline \multirow{2}{*}{ TRANSITION } \\
(Fim de Tubo / P+L) & Transition stage (End of Pipe + CP) & 7 \\
\hline END OF PIPE & Waste treatment, incineration, landfill & 11 \\
\hline Total & & $\mathbf{3 6}$ \\
\hline
\end{tabular}

Source: based on the company's EMS documents (2006)

As observed in Table 8, End of Pipe actions (waste treatment and disposal technologies) are evident among the modalities adopted to reduce pollution, with a total of eleven actions presented in Table 3: Stages in the process, waste and destination.

It is important to register that the Environmental Management System certified to ISO 14001 does not establish conditions to minimize the use of End of Pipe techniques. As to Cleaner Production methodology, it does not recommend the adoption of these techniques, but it does not discard them either. According to Christensen (2002), a greater concern about waste generating processes is evident in companies making use of clean technologies.

Seven actions classified at the level of transition between End of Pipe techniques and Cleaner Production are presented in Table 3. Whenever possible, Level
1 (reduction at source), followed by Level 2 actions (internal recycling) should take priority; in the company studied, priority is given to Level 3 in the Flow chart (external recycling and biogenic cycles). The company has been resorting to external recycling as the main technique for disposal of waste, since sixteen actions using this approach were identified.

As to Good Operational Practices, only two actions were identified. According to the literature referring to Cleaner Production approaches, Good Operational Practices usually correspond to low costs and easy applicability.

The percentage of use of each type of strategy for waste reductions is represented in Figure 6, demonstrating that $31 \%$ of the actions adopted to reduce and control waste refer to End of Pipe techniques, i.e. actions aiming at waste treatment, incineration and final disposal. 
Figure 6: Use of strategies for waste reduction and prevention

\section{Use strategies for waste reduction and prevention}

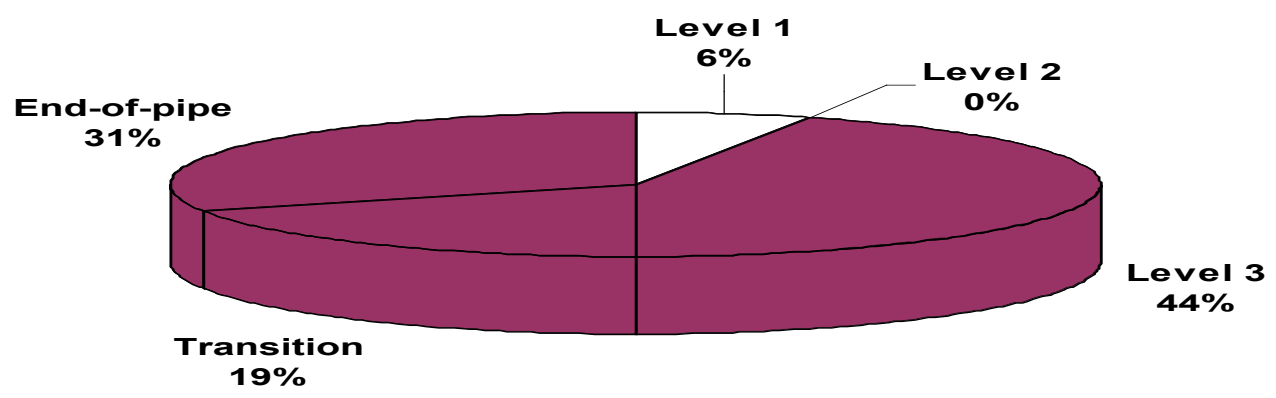

Source: based on the company's EMS documents (2006)

The actions classified between End of Pipe and Level 3 represent $19 \%$ of the total and, according to Table 3 , in this case study are named Transition Techniques, which characterize the processes of waste modification for use as sub product or for reuse of caloric power. Level 3 accounts for $44 \%$ of waste reduction actions, i.e. they are basically external recycling actions in which waste generated is used as raw material in other companies.

As seen in Figure 6, no actions were noted for Level 2. At Level 1, only actions that are not related to waste prevention or minimization were found; they are actions that aim at directly or indirectly reducing the consumption of natural resources, such as water and electricity, and account for $6 \%$ of pollution prevention actions.

The results of this study demonstrate that the company in question, despite having an Environmental Management System certified to ISO 14001, still engages in non-satisfactory environmental conduct, as regards waste, albeit with a tendency for evolution. Figure 4 shows that $94 \%$ of the actions aiming at pollution prevention and reduction are classified between End of Pipe Techniques and Level 3 (External Recycling). These techniques are compatible with the environmental strategy, which is predominantly reactive, since the emphasis at present is on complying with the legislation in force and on conformity with ISO 14001. To Corbett (2001), ISO 14001 does more, in environmental terms, for dirtier facilities than for cleaner ones.

Klassen (1999), suggests that senior management to assist plant mangers to become more proactive and to improve environmental performance.

\section{CONCLUSION}

Cleaner Production concepts recommend waste reduction or suppression. It may be concluded that an Environmental Management System based on ISO 14001 and complemented with Cleaner Production widens the context for environmental performance improvement.

ISO 14001 certification has been valued as a parameter for companies' environmental qualification, and consequently, as a strategic advantage in the fight for market positions, considering the value attributed to the environment by some segments of society. Thus, certification is directly associated to environmental quality.

It can be verified that ISO 140001 certification contributes to improving environmental management in companies. That System complies with environmental legislation and requires a commitment of the certified company to a continuous search for improvement in environmental actions.

However, the EMS certified to ISO 14001 can generate a climate of false tranquility, in which the system behaves satisfactorily from a normative point of view, but the environmental performance itself may not be satisfactory, since this model does not represent environmental excellence but is rather a management frame in the search for continuous improvement.

The scope of the insertion of a Cleaner Production Program into an EMS already implemented depends on the economic, technological and managerial capacity available. Cleaner Production demands orientation towards innovation and a continuous improvement process, with an accumulation of experience and resources saved with the first inter- 
ventions, providing impulse for new actions. It is obvious that a zero emission target is not attainable throughout the production chain, since transformation without loss is a physical impossibility, but it is applicable to specific questions, such as the elimination of toxic waste.

The environmental strategy of preventing pollution presupposes the adoption of Cleaner Production concepts, which represent the base of High Performance Environmental Management. In this strategy, the best economic alternative is the elimination, rather than the management of environmental impacts, i.e. the focus is the opposite of End of Pipe Technologies.

This case study showed that the Cleaner Production Program may offer contributions to an Environmental Management System certified to ISO 14001, since the Cleaner Production approach favors solutions aiming at waste reduction and prevention, suggesting that companies act at the generating source, seeking alternatives for the development of an eco-efficient process, resulting in non-generation of waste, in reduction, in internal or external recycling.

The integration of the Cleaner Production Program with the Environmental Management System certified to ISO 14001 guarantees better knowledge of the industrial process by means of constant monitoring for the maintenance and development of an eco-efficient production system, with the generation of environmental and process indicators. This monitoring allows the company to identify applied research, technological information and training program needs. The Cleaner Production Program can be integrated with Quality Systems, Environmental Management and Occupational Safety and Health, resulting in complete understanding of the company's management system.

The Cleaner Production Program brings environmental and economic benefits that result in global efficiency in the production process, through elimination of avoidable losses, minimization or elimination of raw materials and other supplies that have a negative impact on the environment, a reduction of waste and emissions, a decrease in waste management costs, minimization of environmental liabilities, improvement in health and safety at work.

According to this study, the model of management proposed by ISO 14001 favors the practice of managing waste and administering the environmental impacts of the activities of the company. In terms of environmental performance, better results may be obtained when the Cleaner Production Program concepts are aggregated as a complementary instrument to the Environmental Management System certified to ISO 14001, resulting in a sustainable EMS, considering that the implementation of the Cleaner Production Program emphasizes waste prevention at the source.

As observed in the literature and through analyses and observation of the company's documents, the continuous improvement demanded by ISO 14001 is no guarantee of significant improvement in environmental performance, since the company may adjust to the norm with an inefficient management model. The standardization of procedures demanded by normalization may make the company adopt correct traditional procedures, but with poor environmental performance; therefore, the Cleaner Production approach is a necessary complement to the Environmental Management System.

For future studies, it is recommended that reasons for use of End of Pipe technologies be verified, to see if this is due to a behavior of resistance to change, which prevents the adoption of a posture based on Pollution Prevention, or whether the cause lies in the ignorance of the existence of alternative models, or in restrictions on financial investment.

\section{BIBLIOGRAPHY}

BARBIERI, Carlos J. Gestão Ambiental Empresarial - Conceitos, Modelos e Instrumentos. São Paulo: Saraiva, 2004.

CNTL - SENAI RS. Manual de Implementação de programas de Produção Mais Limpa. Porto Alegre: Centro Nacional de Tecnologias Limpas Senai-RS/UNIDO/UNEP, 2003.

CHRISTENSEN, Per Coping with the Environment - Danish companies and their experiences with ISO 14001/EMAS. The Journal of Transdisciplinary Environmental Studies, vol.1, n. 1, 2002, ISSN 1600-2297. Disponível em <www.journal-tes. dk> Acesso em 25 de maio de 2006.

CHRISTIE, I.; ROLFE, H.; LEGRAND, R. Cleaner Production in Industry, Londres, Policy Studies Institute, 1995.

COBERTT, C. J., RUSSO M. V. The impact of ISO 14001. ISO Management Systems.

EISENHARDT, K.. M.; GRAEBNER, M. E. Theory building from cases: Opportunities and challenges. Academy of Management Journal 2007, vol. 50, n. 1, 25-32.

FINK, Ronald G. Recycling waste water. Pit \& Quarry, jul-95, vol. 88, p.23, 3p. ISSN-0032-0293. 
FRIEDMANN, C. Aspectos tecnológicos de la gestion de resíduos. In FUENTE, H. D. de la (org). Gestion ambientalmente adecuada de resíduos sólidos. CEPAL/GTZ. Santiago de Chile, 1997.

FURTADO, João S. e FURTADO, M. C. Produção Limpa, in Contador, J. C. (coord.) Gestão de Operações. Fundação Vanzolini \& Editora Edgard Blucher Ltda., São Paulo, 1998, p. 317-329.

KIPERSTOK, A. Ecologia Industrial e prevenção da poluição: Uma contribuição ao debate regional. TecBahia, Camaçari, v.15, n.2, p.47-55, maio/ago 2000.

KLASSEN, R. D., WHYBARK, D. C. Environmental management in operations: The selection of environmental technologies. Decision Sciences, Summer, 1999, 601-631.

KLASSEN, R. D., MCLAUGHLIN, C.P. TQM and environmental excellence in manufacturing. Industrial Management and Data Systems, 1993, 14-22.
LAGREGA, MD ET AL. The Environment resource Management Group: hazardous waste management, 1st ed. Singapore. Mc graw-Hill, 1994, 1146p.

PRESTRELO, R.C; AZEVEDO, P. R. $\quad$ ISO 14000 \& Produção Mais Limpa: solução para um Sistema de Gestão Ambiental mais efetivo ou abrangente. 2000. 80f. Monografia (Especialização de Gerenciamento de Tecnologia Ambientais na Industria) Escola Politécnica, Universidade Federal da Bahia, Salvador.

NICOLAJ, SIGGELKOW. Persuasion with case studies. Academy of Management Lournal 2007, Vol. 50, n. 1, 20-24.

UNEP - Declaração Internacional sobre Produção Mais Limpa. 1998. Disponível e <http://www.uneptie.org/pc/cp/declaration/> Acesso em: 02 junho 2006.

YIN, R. K. Estudo de Caso - Planejamento e Método. Porto Alegre: Bookman, 2001.

\section{BIOGRAPHY}

Fernando M. Cervelini, earned his Master's degree in Administration with emphasis on Production Control at Nove de Julho University and Bachelor's Degree in Electric Engineering at Mogi das Cruzes University. Nowadays, he is a professor of Cleaner Production and Sustainability Development at Estácio UniRadial University. He also has held several positions at multinationals companies in Brazil acting since 1987 in areas as industrial maintenance, environmental and manufacturing.

Maria Tereza Saraiva de Souza is Professor at the Nove de Julho University. In the Doctorate and Masters's Degree Programme, she teaches classes about Environmental Management and also advises students in their doctorate thesis and Master's degree dissertation developing research in the field of Environmental Management.

She has publications in the main Business Administration Congresses, with emphasis on sustainability, social responsibility, reverse logistics, green-supply chain management and Cleaner Production. She has experience in academic administration, such as the department head during the periodo 1994-2006 and others executive positions in brazilian universities.

She earned a Doctorate and Master's degree in Business Administration from EAESP/FGV. 